\title{
Recurrent acute pancreatitis
}

INSERM

\section{Source}

INSERM. (1999). Orphanet: an online rare disease and orphan drug data base. Recurrent acute pancreatitis. ORPHA:64740

A disorder that is characterized by repeated attacks of acute pancreatitis (AP), which is defined as an acute inflammatory process of the pancreas with variable involvement of other regional tissues or remote organ systems. 